\title{
Enhancing Employees' Commitment to Organisation through Training
}

\author{
Owoyemi, Oluwakemi Ayodeji, $\mathrm{PhD}$ \\ Department of Industrial Relations and Personnel Management, Faculty of Business Administration \\ University of Lagos, Nigeria \\ E-mail: oowoyemi@unilag.edu.ng \\ Oyelere, Michael, PhD \\ European Business School London, Department of Management and Human Resources \\ Inner Circle, Regent's Park, London, United Kingdom \\ E-mail: OyelereM@REGENTS.AC.UK \\ Elegbede, Tunde \\ Department of Industrial Relations and Personnel Management, Faculty of Business Administration \\ University of Lagos, Nigeria \\ E-mail: telegbede@unilag.edu.ng \\ Gbajumo-Sheriff, Mariam (Corresponding author) \\ Department of Industrial Relations and Personnel \\ Management, Faculty of Business Administration \\ University of Lagos, Nigeria \\ Tel: 234-803-714-8629_E-mail:mgbajumo@unilag.edu.ng
}

Received: November 29, 2010 Accepted: February 12, 2011 doi:10.5539/ijbm.v6n7p280

\begin{abstract}
The role of training in human resource management practice has spur renewed and vigorous debate about the need for training and development. The debate has led academics and management to ponder on some issues germane to the benefits or otherwise of training. Is training an investment in people or cost? If training is required, what are the criterion used to determine who should be trained and when to train? These questions have permeated management circle and those in HRM department. Recent years have seen training terms renamed as training and development or learning and development, a sign of the spate of debate on the issue. Given these flurry, this paper explores the relationship between training and employees' commitment to their organisation. The paper was based on a survey of 250 employees and management staff of a financial firm based in the South Western part of Nigeria. Statistical Package for the Social Sciences (SPSS) was used to conduct several forms of analysis. The analysis revealed some evidence that suggest a positive statistical significant relationship between the different levels of training and employees' commitment to organisation. A regression analysis was conducted on the data collected. The study revealed a positive statistical significant relationship between the different levels of training and employees' commitment to the organisation. The paper concludes that the more the training giving to employees, the higher their level commitment to the organisation.
\end{abstract}

Keywords: Training, Commitment, Performance, Human Resources, Management

\section{Introduction}

The economic downturn is causing much concern about the potential decline in training, learning and development of employees. The conventional knowledge is that most employers cut back on employees training during recession to save production cost. This paper emphasise the importance of maintaining training, learning and development levels during recession. This is based on two main suppositions; first, training improves employees' commitment to the organisation, and second, committed employees are likely to be more productive. In essence, in order for employers to remain competitive and maintain high level of performance, employers are employed not to cut back on employees' training, learning and development needs.

Training has been a subject of debate with various functions and definitions. Some authors define training as the ability of an organisation to develop skills and knowledge to do present and future job (Guest, 1997; Guest, 
Michie, Conway \& Sheehan, 2003); training is a content-based activity, normally away from the workplace with an instructor leading and aiming to change individual behaviour or attitude (Mullins, 2010); conversely, others sees it as an important employee motivator (Barret \& O'Connell, 2001). Training from a company's perspective adds to human capital and also a means of securing workplace commitment. The theoretical proposition therefore is that training is likely to lead to employees' commitment to the organisation.

There is no general agreement as to what can increase an employee's commitment to the organisation. Most behavioural learning theorist agreed on this point (see Haleblian, and Finkelstein, 1999; Campbell, and Wasley 1993; Puffer, and Weintrop 1991). Most of the conceptualization of commitment used in most of the American studies reflects more of managerialist and unitarist outlook (Guest, 2000). Other labels such as high commitment (Boxall \& Macky, 2009; Guest et al., 2003), lean production (MacDuffie \& Kochan, 1995), security employee involvement (Guest et al., 2000; 2003) have been given, even though most of them are focused on effective work management. While these studies have been useful for demonstrating the potential value created through HR practice, they have revealed very little regarding the process through which this value is created (Wright et al., 2003). That is why we may believe that HR practices are driving employees' commitment, but unable rule out the possibilities of the reverse (Wright et al., 2003).

\section{High Commitment Work Practices}

Commitment according to Jaw and Liu (2004) is not only a human relation concept but also involves generating human energy and activating human mind. Without commitment, the implementation of new ideas and initiatives will be compromised (see Ramus and Steger 2000 cited in Jaw \& Liu, 2004). Human resource system can facilitate the development or organisational competencies through eliciting employees' commitment to the firm (Arthur, 1994; Boxall \& Macky, 2009). Hence organisations with a fit business strategy, structure and practices and policy might perform better. Walton (1995) prescribed "commitment" as a distinctive strategy for HRM whose positive effect will be felt.

High commitment work practice according to Guest (2003) is an approach to managing employees, which emphasises is on the need to develop organisational commitment amongst employees based on the assumption that it will lead to positive outcomes such as low labour turn over, absenteeism, better motivation and improved performance. Several academic researches on human resource management practices suggested that high commitment human resource practices will increase organisational effectiveness by creating a condition whereby employees become highly motivated and involved in the organisational activities aimed at achieving organisational goals (see Arthur, 1994; Abu-Baker, 2010; Boxall \& Macky, 2009). Superior performance has been linked with organisations that implement this practices based on the fact that 'commitment approach' as classified by (Walton, 1995) is used, which aims at increasing effectiveness, productivity and rely on conditions that encourages employees to identify with the goals of the organisation and also work in order to achieve common goals (Sweetman, 2001). Moreover, recent studies have shown that high commitment practices can work well synergistically and a reflective of a general commitment strategy (Sweetman, 2001).

Evidences derived from social science researches have shown that there is now a broad agreement amongst commentators that high commitment work practices do improve performance, labour productivity and the quality of service (Boxall \& Macky, 2009; Marchington 1994; Pfeffer 1994). Although researchers such as Boxall and Macky (2009) and Purcell, Kinnie, Hutchinson, Rayton and Swart (2003) have argued that the majority of previous studies have looked at high commitment work practices from the employers' perspective, and the over dependence on such perspectives can sometimes be mis-leading and will not present the real impact on organisational performance. Nevertheless, when employees positively interpret high commitment work practices, it will sequentially increase their commitment to the organisation, thereby increasing their individual performances and hence organisational performance will also increase (Purcell et al., 2003; Peccei, 2004). Although a commitment strategy can be tied to all company human resource practices; recruitment, selection, performance evaluation, according to Scholl (2003), it can also be used to develop psychological connections between the company and employee as a means of achieving goals (Arthur, 1994; Scholl, 2003).

\section{Employees' Training and Development Explored}

Most training literatures have emphasised the benefits organisational gained from adopting a systematic approach to human resource learning and development. The development of skills underpins organisational business objectives (Keep, 1989). Studies have shown that most organisations devote little attention to the evaluation of training effectiveness (Keep and Rainbird, 2000). Companies can seek to achieve organizational goals through a variety of human resource strategies and approaches and the importance of ensuring employees' commitment and retention following training may lie in the strategic approach that is utilised. In an attempt to ensure that the employee remains with the company following training, employers may implement a strategy to training that fosters commitment. Training according to Brum (2010), Owen (2006) will increase employees' commitment, which can further counter the numerous direct and indirect costs associated with employees' turnover. 
Nigerian has been consistently criticised for its low levels of workplace training and development (Fajana, 2002). Identifying why employers are failing to train according to Keep and Rainbird (2000) is an attempt to find the solution to the problem. Amongst the explanation given were the market failure, lack of information and inadequate individual resources (Lloyd, 2002). Other commentators have argued that the training failure is more systematic and a reflection of Nigerian' economy and organisational culture. Even though the lack of training in Nigerian workplaces has sometimes been blamed on the lack of interest amongst workers, recent studies disprove this assertion. Most fingers are now being pointed at the employers, who are trying everything possible to reduce running cost, especially now that there is a global economic down turn. Although various reports have been given on the positive impact of training on organisational commitment (Boxall \& Macky, 2009; Fleetwood \& Hesketh, 2006); Guest et al., (2003) argued that for the effect of training to be felt, its values must lie in the part it can play in the integrated HRM strategy, especially when there has been so much investment in high quality and flexibility of the workforce.

\section{Statement of Problem}

The study investigates the relationship between training and commitment in a financial service organisation in South-Western Nigeria. This paper therefore looks at training as a single practice in the financial service organisation and its effect on employees' commitment to their organisation, within a supposition that establishments that provide training to their employees are likely perform better than organisations that do not. This argument is based on the premise that some HR practices such as 'Training' may be perceived as a 'gift' from the employers (following Barrett and O'Connell, 2001). The effect of such gift according to Brum (2010) will make employees to exert more effort, become more productive, and have a greater sense of debt to the organization. Brum further argues that the 'training as a gift' from employers also has the potential to make employees feel like insiders into the organisation and are more likely to be more committed and devoted to the company. The idea parallels closely to the concept of reciprocity, that emphasises that employee will help the organisation, because the organisation helped to employee (Brum, 2010). Thus, when an organisation meets such expectation, employees are most likely to reciprocate.

\section{Objectives for the Study}

Specifically, the objectives of the study are to:

1) Explore the relationship between training and employees' commitment to the organisation.

2) To determine if an increase in the amount of training employees have will increase their level of commitment to the organisation.

Given the position of the existing literature on the relationship between training and commitment, the following hypothesis is developed

Null Hypothesis: There is no statistical significant relationship between training and employees' commitment to the organisation.

Alternative Hypothesis: There is a positive statistical significant relationship between training and employees' commitment to the organisation.

\section{Methodology}

The target population for the study consists of all the employees of Financial Service organisation in South-Western Nigeria. A total of 250 respondents, which represents seventy five percent of the total population, returned the questionnaire distributed. The respondents consist of 120 (48\%) male employees and $130(52 \%)$ female employees. (See Table 1: Overview of the Respondents in the Appendix). The purposive and stratified sampling technique was used to select the respondents. The hypothesis tested in this paper is based on the comprehensive analysis of the argument that surrounds training and commitment.

\subsection{The Model of Analysis}

The model of analysis will be based on regression analysis, where

$$
\mathrm{Y}=\mathrm{bo}+\operatorname{bi}(\mathrm{X})+\operatorname{bii}(\mathrm{Xii})+\operatorname{biii}(\mathrm{X}) \ldots \ldots . . . \mathrm{bp}(\mathrm{Xp})
$$

Where $(\mathrm{Y})$ is the dependent variable (commitment) (X, Xii, Xiii....Xp) are the independent variables, (bi, bii, biii...bp) are the coefficient which can also be the slope, (bo) is the intercept or the constant upon which the independent variables are based on. The research model and equation will be as follows

$$
\text { Commitment }=\text { Constant }+ \text { Level of Training } \ldots . . . \text { equation (1a) }
$$

The variable "commitment" was used to measure all the responses to the question 'do you feel committed to the organisation"? The responses to the question were recoded and broken down into those that strongly agree, agree, neither agree or disagree, disagree, strongly disagree and the missing value (-999) for no response. The independent variable "training" was also broken down into different levels of training based on the number of days that employees were trained. The levels of training were Less than one day training, for those who had received training for less than one day, Less than two days training for those who had received training for 1 to 2 days, Less than five days training for those that have received training for 2 to 4 days, Less than ten days 
training for those that had training for 5 to 10 days and finally, Ten or more days training is for those who had received more than 10 days training. The levels of training and the proportion of employees that had been trained as the independent variables are expected to affect employees' commitment.

\section{Results}

The results in the summarised table showed that training is positively and strongly correlated with employees' commitment to the organisation. The hypothesis that there is a positive statistical significant relationship between training and employees' commitment to the organisation stated in the previous section has therefore been supported. The result of analysis is illustrated in the table below

The table 2 below shows that the employees that had less than one day training has a standard error of (.0245801) and the coefficient is (.0363487). The $(\mathrm{Z}=1.48)$ and it is significant at $5 \%$. The other levels of training such as the less 2 , less 5, less 10 , less 10 and more than 10 days training all had a standard error showing $(.0201217, .0242390, .0232076, .0175707)$, coefficients $(.155000, .253328, .3147034, .301899$ respectively) and $(\mathrm{Z}=7.7,12.46,13.56,14.42)$ respectively and all are significant at $1 \%$. The results showed that the size of coefficients is increasing as the level of training increases. These results suggest that the more training given to employees, the more committed they will be to the organisation. The positive sign indicates the direction of the relationship. That is, the more training given, the more committed an employee will be to the organisation. Porter and Tripoli (1997) reported similar results that training signals commitment from the organisation to the employees, which will result in employees reciprocating such behaviour by demonstrating a stronger affective organisational commitment, which is quite productive and can affect performance. Although the direction of causality cannot be truly established, the results are in line with other findings (see Black and Lynch 1996; Gallie and White cited in Santos and Stuart 2003). Another empirical evidence and theoretical argument that supports these were also given by Keep (1998), in his study of 3,585 employees in the Employment in Britain Survey; he found that $94 \%$ of the employees felt that training is beneficial in terms of achieving qualification, gain promotions, increase earnings and likewise non financial benefits in terms of commitment and job satisfaction. In a more recent study, Owens (2006) also reported a significant relationship between training and organisational outcomes. He found that employee's in training programs increases the levels of commitment. All these aforementioned research affirmed the hypotheses that training has a positive impact on employees' commitment and turnover.

\section{Discussion}

Commitment within the workplace typically results from the interaction and the relationship that an employee has with an organization (Scholl, 2003). The statistical analyses have shown that the more training given to employees', the stronger employees' commitment to the organisation. When an organisation provides training to employees, the chances of better performance is enhanced. The research supports the existing literature that training is likely not only to increase and improve employees' knowledge and skill, rather, it is also a means of achieving higher organisational commitment and performance. It is suggested that training should be implemented as part of the larger organisational development strategies aimed at getting a committed workforce. This is because employees interpret training as an indicative of commitment from the organisation to them, and which they may reciprocate through their committed to the organisation. The major finding is that businesses that were operating below their expected labour productivity levels prior to providing and implementing new employees' training, learning and development programs that resulted in significantly larger increases in labour productivity growth should understand the significance of training programmes to employees' productivity and organisational objectives. This higher rate of productivity growth is sufficient to bring these businesses up to the labour productivity levels of comparable businesses.

Based on the findings, this paper suggests that by adopting and increasing employees' training, organisations are likely not only to support the growth and development of their employees, but conversely, creating and facilitating increased organisational output. In the main, this is likely to lead to the actualisation of organisational objectives and ensure competitive advantage over its competitors.

Given the above, we can conclude that training will not only improve the technical and non- technical skills of the employees, but it can be used to get employees committed to the organisation. The effect of training in this situation is positive and beneficial to the financial service organisation. Employers should therefore invest more in training, learning and development of their employees in order to ensure better performance. The human resource management practitioners should integrate employee training, learning and development into HRM practises aimed at getting a committed workforce and also practices aimed at increasing organisational performance (Fleetwood \& Hesketh, 2006; Huselid 1996). Furthermore, access to training according to Brum (2010) can also play a significant role into the level of commitment that is established. That is, employees are likely to place greater value on training programs that are more frequent and highly respected by colleagues, supervisors, and managers. Bartlett (2001) argues that organisations that are able to create an environment where training is supported and valued by employees will be able to achieve greater commitment outcomes such as low employees' turnover. 
Furthermore, the policy-makers should also put in place polices that will be tailored at organisations that are yet to put into place employees' training and development programmes in their management strategies. Creating awareness of its importance will go along way in ensuring management's commitment to employees training, learning and development. There is also the need to enlighten the general public on the sine qua non and overall effect of training on employees' commitment to the organisation.

\section{Limitations of the Study}

This research has adopted a one-sided approach of the effect of training, learning and development on employee attitude in terms of commitment. Training from another perspective can be expensive and cost-effective. Although this result suggests that it is beneficial to both employees and employers, it did lay much emphasis on the fact that training can increase the operational cost of running an organisation which can reduce the gross profit for those establishments that are large and those that train most of their employees. The cost implications can be either monetary in terms of money spent on training or non monetary or intangible in terms of times spent while been trained or while giving out training. Furthermore, establishments that train might also be at a higher risk of losing their most efficient and better-trained employees to other organisations that are ready to offer them more pay in terms of their well-developed skills.

\section{Conclusions}

The main purpose of this paper is to investigate the relationship between training, learning and development to commitment. The result using a regression model showed that, the more training given to employees, the more committed they will be to the organisation. This result is consistent with other research and findings on the relationship between training and employees' commitment to the organisation. The underlying philosophy therefore is the need for management to acknowledge and openly accept that training is one of the commitment-based strategies that can be utilised to enhance organisational performance. In conclusion, training is a tool that can assist in building a more committed and productive workforce and can lead to greater commitment and less employee turnover. Based on these findings, effective training program can lead to greater employee commitment and a more stable workforce.

\section{References}

Abu-Baker, M. (2010). The Role and Impact of Family Friendly Work Practices in the Contect of Middle Eastern Organisations. Doctorial Symposium. Research Institute for Business and Management, Manchester Metropolitan University Business School.

Argyris, C. (1998). Empowerment: The Emperor's New Cloth. Havard Business Review, 76 (3), 98 -105.

Armstrong, M. (2003). A hand book of Human Resource Management Practice, Kogan.

Arthur, J. (1994). Effects of Human Resource System on Manufacturing Performance and Turnover, Academy of Management Journal, 37 (3), 670 -687.

Barrett, A., and O' Connell, P. (2001). Does Training Generally Work?: The return to In- Company Training. Industrial and labour Relations Review, 53 (3), 647-662.

Bartel, A. (1994). Productivity Gains from the Implementation of employee Training Programme. Industrial Relations, 33 (4), 11- 425

Bartlett, K. (2001). The Relationship Between Training and Organizational Commitment: A Study in the Health Care Field. Human Resource Development Quarterly, 12(4), 335-352.

Boxall, P., and Macky, K. (2007). The relationship between 'high-performance work practices' and employee attitudes: an investigation of additive and interaction effects. International Journal of Human Resource Management, 18(4): 537-67.

Boxall, P., and Macky. K. (2009). Research and theory on high-performance work systems: progressing the high-involvement stream. Human Resource Management Journal, 19: 3-23.

Brum, S. (2010). What Impact Does Training have on Employee Commitment and Employee Turnover. [Online] Available: http://www.uri.edu/research/lrc/research/papers/Brum-Commitment.pdf. (January, 2011).

Campbell, C. J., and Wasley, C. E. (1993). Measuring performance using NASDAQ Returns. Journal of Financial Economics, 33: 73-92.

Delery, J., and Doty, D. (1996). Modes of Theorising in Strategic Human Resource Management: Test of Universalistic, Contingency and Configurational Performance Prediction. Academy of Management Journal, 34 (4), $803-835$.

Fajana, S. (2002). Human Resource Management: An Introduction. Labofin and Company, Lagos.

Fleetwood, S., and Hesketh, A. (2006). High Performance Work Systems, Organisational Performance and (Lack of) Predictive Power. Journal of Critical Realism 5 (2), 228-250.

Guest, D. (1997). Human Resource Management and Performance. International Journal of Human Resource Management, 8 (3), 263-275. 
Guest, D., Michie, J., Sheehan, M., and Conway, N. (2000). Getting inside the HRM Performance Relationship: An ESRC Research Programme on Future of work, School of Management and Organisational Psychology Birkbeck College, University of London.

Guest, D., Peccei, R., and Thomas, A. (1993). The Impact of Employee Involvement on Organisational Commitment and 'them and us' Attitudes. Industrial Relations Journal, 23 (3), 190 -200.

Guest, D.E., Michie, J., Conway, N., and Sheehan, M. (2003). Human Resource Management and Corporate Performance in the UK. British Journal of Industrial Relations, 41 (2): 291-314.

Haleblian, J., and Finkelstein, S. (1999). The Influence of Organizational Acquisition Experience on Acquisition Performance: A Behavioral Learning Perspective. Administrative Science Quarterly, 44 (1), 29 - 56

Heyes, J., and Stewart, M. (1994). Placing Symbols before Reality? Re-evaluating the Low Skills Equilibrium. Personnel Review, 23 (5), 34- 49.

Huselid, M. (1995). The Impact of Human Resource Management Practices on Turnover, Productivity and Corporate Financial Performance. Academy of Management Journal, 38 (3), 635 - 672.

Jaw, B., and Liu, W. (2004). Promoting Organisational Learning and Self Renewal in Taiwanese Companies: The Role of HRM. Human Resource Management, 42 (3), 223 -241.

Keep, E., Mayhem, K., SKOPE and McConsulting. (2002). Review of the Evidence on the Rate of Employers of Investment in Training and Employer Training Measures. SKOPE Research, Paper 32.

Kraiger, K., McLinden, D., and Casper, W. (2004). Collaborative Planning for Training Impact. Human Resource Management, 43 (4), 337 -351.

Lloyd, C., and Payne, J. (2004). Just Another Bandwagon? A Critical look at the Role of High Performance Workplace as Vehicle for UK High Skill Project, SKOPE Research Paper 49.

MacDuffie, J. (1995). Human Resource Bundles and Manufacturing Performance: Organisational logic and flexible Production Systems in the World Auto Industry. Industrial and Labour Relational Review, 48 (2), 192-219.

MacDuffie, J., and Kochan, T. (1995). Do US Firms Invest less in Human Resources? Training in the World Auto Industry. Industrial Relations, 34 (2), 147- 168.

Marchington, M., Goodman, J., Wilkinson, A., and Ackers, P. (1992). New Development in Employee Involvement. London, Employment Department Research Series 2.

Mullins, L. (2010). Management and Organisational Behaviour $9^{\text {th }}$ Ed Prentice hall, London, England

Owens, P. L. (2006). One More Reason Not to Cut your Training Tudget: The Relationship between Training and Organisational Outcomes. Public Personnel Management, 35(2), 163-171.

Peccei, R. (2004). Human Resource Management and the Search for the Happy workplace.

Peters, T and Waterman, R. (1982). In Search of Excellence: Lessons from America's Best-Run Companies, New York, Harper and Row.

Pfeffer, J. (1994). Competitive Advantage through People: Unleashing the Power of Workforce, Boston, Harvard Business School Press.

Puffer, S. M., and Weintrop, J. (1991). Corporate performance: The role of performance expectations. Administrative Science Quarterly, 36 1-19.

Purcell, J., Kinnie, N., Hutchinson, S., Rayton, B., and Swart, J. (2003). Understanding the People and Performance Link: Unlocking the Black Box. The Chartered Institute of Personnel and Development, London.

Rotterdam, Erasmus Institute of Management (ERIM).

Santos, A., and Stuart, M. (2003). Employee Perception and their Influence on Training Effectiveness. Human Resource Management Journal, 13 (1), 27-56.

Scholl, R.W. (2003). [Online] Available: http://www.uri.edu/research/lrc/scholl/Notes /Commitment_Control.html accessed January 2011.

Sweetman, K. (2001). Employee Loyalty around the Globe. Sloan Management Review, 42 (2) 10-16.

Walton, R. (1995). From Control to Commitment in the Workplace. Harvard Business Review, 63 (2), 76-84.

Whitfield, K. (2000). High Performance Workplaces, Training and Distribution of Skills. Industrial Relations, 39 (1) $1-25$

Wright, P., and Gardiner, T. (2000). Theoretical and Empirical Challenges in Studying the HR Practice-Performance Relationship: A Paper Presented at the Special Workshop, Strategic Human Resource Management, European Institute for Advanced Studies in Management, INSEAD, France.

Wright, P., Gardner, T., and Moynihan, L. (2003). The Impact of HR practices on the Performance of Business Units. Human Resource Management Journal, 13 (3), 21 -31. 
Table 1. An Overview of the Respondents

\begin{tabular}{|c|c|c|}
\hline Descriptive & $(\mathrm{N}=\mathbf{2 5 0})$ & Per cent $(\%)$ \\
\hline \multicolumn{3}{|l|}{ Gender } \\
\hline Female & $(\mathrm{N}=120)$ & $48.0 \%$ \\
\hline Male & $(\mathrm{N}=130)$ & $52.0 \%$ \\
\hline \multicolumn{3}{|l|}{ Age } \\
\hline $21-30$ & $(\mathrm{~N}=80)$ & $32.0 \%$ \\
\hline $31-40$ & $(\mathrm{~N}=125)$ & $50.0 \%$ \\
\hline $41-50$ & $(\mathrm{~N}=45)$ & $18.0 \%$ \\
\hline \multicolumn{3}{|l|}{ Marital Status } \\
\hline Single & $(\mathrm{N}=90)$ & $36.0 \%$ \\
\hline Married & $(\mathrm{N}=140)$ & $56.0 \%$ \\
\hline Widowed & $(\mathrm{N}=15)$ & $6.0 \%$ \\
\hline Divorced/Separate & $(\mathrm{N}=5)$ & $2.0 \%$ \\
\hline \multicolumn{3}{|c|}{ Academic Qualification } \\
\hline HND, B.Sc., B.A & $(\mathrm{N}=121)$ & $48.4 \%$ \\
\hline MBA, M.Sc., M.A. & $(\mathrm{N}=129)$ & $51.6 \%$ \\
\hline \multicolumn{3}{|l|}{ Work Experience } \\
\hline Less than a year & $(\mathrm{N}=30)$ & $12.0 \%$ \\
\hline $1-5$ years & $(\mathrm{N}=134)$ & $53.6 \%$ \\
\hline $6-10$ years & $(\mathrm{N}=76)$ & $30.4 \%$ \\
\hline $11-15$ years & $(\mathrm{N}=10)$ & $4.0 \%$ \\
\hline \multicolumn{3}{|c|}{ Status of Respondent } \\
\hline Management staff & $(\mathrm{N}=68)$ & $27.2 \%$ \\
\hline Senior staff & $(\mathrm{N}=92)$ & $36.8 \%$ \\
\hline Junior staff & $(\mathrm{N}=90)$ & $36.0 \%$ \\
\hline
\end{tabular}

Table 2. Table showing the Relationship between Training and Commitment

\begin{tabular}{|c|c|c|c|c|}
\hline \multicolumn{5}{|c|}{ Equation : $Y($ commitment $)=$ function* bi $($ Training $)$} \\
\hline \multicolumn{5}{|c|}{ Number of observations $=250$} \\
\hline Variables & Coef. & Std. Err. & $\mathrm{z}$ & $\mathrm{P}>|\mathrm{z}|$ \\
\hline Less than 1day training & .036348 & .0245801 & 1.48 & $0.139 *$ \\
\hline Less than 2days training & .155000 & .0201217 & 7.70 & $0.000 * * *$ \\
\hline Less than 5 days training & .253328 & .0242390 & 12.46 & $0.000 * * *$ \\
\hline Less than 10 days training & .314703 & .0232076 & 13.56 & $0.000 * * *$ \\
\hline More than10days training & .301899 & .0175707 & 14.42 & $0.000 * * *$ \\
\hline
\end{tabular}

